\title{
From Marx to Market: The Debates on the Economic System in Vietnam's Revised Constitution
}

\author{
PHAM Duy Nghia* \\ University of Economics, Ho Chi Minh City, Vietnam \\ nghiapd@ueh.edu.vn
}

\begin{abstract}
This article analyzes the socio-economic and political contexts behind the $20{ }_{3} 3$ Constitution of the Socialist Republic of Vietnam (2013 Constitution), in which demands for deeper institutional reform emerged in Vietnam, and explains the constitutional discourse within Vietnam as to its economic order. Diverse forces and platforms within Vietnam's party-state and beyond have contributed to the exchange of ideas and values on the economic order. As a result of this public discourse, the provisions on the economic order of the $20 \mathrm{I}_{3}$ Constitution are ideological compromises, reflecting the contradicting views within the party-state and society in Vietnam on the role of the market, private property, and the freedom to conduct business. The 2013 Constitution has taken a step towards a free market economy by recognizing the decisive role of the market in the national economy. It emphasizes the importance of the private sector and promises that it will be treated fairly among all other economic sectors. From this perspective, the $2 \mathrm{II}_{3}$ Constitution contains the seeds of future political and legal guarantees which could protect individual liberties. However, in line with the socialist ideology adopted by its predecessors, the 2013 Constitution reaffirms the dominance of the public sector and the leading role of state-owned enterprises, and preserves the ambiguous "ownership of the entire Vietnamese people of land and natural resources". Due to this ambiguity, the $20 \mathrm{I}_{3}$ Constitution fails to lay down the foundations for far-reaching comprehensive institutional reforms that Vietnam urgently requires.
\end{abstract}

The 2013 Constitution of the Socialist Republic of Vietnam (2013 Constitution) is Vietnam's sixth constitution. Its first constitution was adopted in I946 when Vietnam became a republic in the aftermath of World War II. ${ }^{\mathrm{I}}$ Following the last revision in

\footnotetext{
* Professor, Fulbright Economics Teaching Program and Faculty of Law, University of Economics, Ho Chi Minh City, Vietnam.

I. After World War II, Vietnam declared its independence in September 1945. The Democratic Republic of Vietnam was founded, and its first constitution was adopted in 1946: 1946 Constitution of the Democratic Republic of Vietnam (adopted 9 November 1946) [1946 Constitution]. By the end of the First Indochina War (1946-1954), the country was divided into two. North Vietnam adopted the 1959 Constitution of the Democratic Republic of Vietnam (adopted 3 I December 1959) [ I959 Constitution], which had a socialist orientation; South Vietnam adopted two constitutions in I 956 and I967 modelled on liberal democracy. The Second Indochina War (I955-I975) ended with the reunification of Vietnam under communist rule. Vietnam was then integrated into the socialist bloc; it adopted the 1980 Constitution of the Socialist Republic of Vietnam (adopted I9 December 1980) [1980 Constitution],
} 
$200 \mathrm{I}$, the constitution was thoroughly rewritten in $20 \mathrm{I} 3$, both in terms of its structure and content. In the $20 \mathrm{I}_{3}$ Constitution, provisions relating to the economic system are now subordinated under the new Chapter III for economic, cultural, educational, technological, and environmental policies. ${ }^{2}$

To understand socialist constitutions, scholars in legal and political studies rely on the instrumentalist approach. Under Marxist-Leninist legal theory, socialist law and constitutions are deemed to be the will of the ruling class, represented by the communist party. This was evidenced by the socialist legal systems adopted by the former Soviet Union and East-European socialist bloc. The applicability of this approach has also been demonstrated through almost 70 years of Vietnam's constitutional history under the rule of the Communist Party of Vietnam (CPV). This instrumentalist approach, widely recognized in constitutional literature, is an essential part of the theoretical framework used in this article to analyze constitutional changes in Vietnam. ${ }^{3}$ Under the instrumentalist approach, the constitution is not considered as binding law which constrains public power and protects individual liberty in socialist countries; rather, it is in essence a political declaration of the ruling communist party. Communist parties have therefore used constitutions as the political means to implement their ideological agendas. Socialist constitutions are subject to frequent changes in order to align them with the ruling party's policies. To ease this process, the procedures for constitutional revisions in socialist countries are generally simplified. ${ }^{4}$

Although socialist countries have core constitutional concepts that are compatible with each other, their policy priorities diverge, and therefore, different constitutional debates have emerged in socialist countries. From country to country, and from time to time, socialist constitutions may use the same terms and concepts, but their meanings and nuances differ significantly. These differing meanings and nuance need to be explained, based on the political and social contexts in each country. ${ }^{5}$ In the case of Vietnam, the 2013 Constitution remains the legal-political means for the CPV to envisage Vietnam's development strategy for decades to come.

which heavily borrowed from the 1977 Soviet Constitution. Following the collapse of the socialist bloc, Vietnam opened for reform, which was cemented by the 1992 Constitution of the Democratic Republic of Vietnam (adopted 25 April I992) [I992 Constitution]. After being amended in 200I, the I992 Constitution was then substantially revised and replaced by a new edition in 2013:2013 Constitution of the Socialist Republic of Vietnam (adopted 28 November 2013) [2013 Constitution].

2. Compare the 2013 Constitution, supra note I, arts 50-55 with the 1992 Constitution of the Democratic Republic of Vietnam (adopted 25 April I992, revised in 200I) [I992 Constitution (200I Rev)], arts I 5-29.

3. For a summary of the instrumentalist approach, see Mark SIDEL, "Analytical Models for Understanding Constitutions and Constitutional Dialogue in Socialist Transitional States: Re-Interpreting Constitutional Dialogue in Vietnam" (2002) 6 Singapore Journal of International and Comparative Law 42 [Sidel, "Analytical Models"].

4. The term "constitutional law" did not exist in the socialist jurisprudence until the late I980s. Instead, the "law of the state apparatus" (Staatsrecht) was taught in socialist legal education institutions, covering political guidelines on the organization of the socialist state and the basic rights and obligations of citizens. The term "constitutional law" only returned to Vietnam in the I990s.

5. In this paper, if needed, I make reference to and compare the socialist economic order as provided by the 1936 Constitution of the Union of Soviet Socialist Republics (adopted 5 December 1936) [1936 Soviet Constitution], I977 Constitution of the Union of Soviet Socialist Republics (adopted 7 October 1977) [ 1977 Soviet Constitution], and the 2004 Constitution of the People's Republic of China (first adopted 4 December I982, amended on I4 March 2004) [2004 PRC Constitution], arts 6-I8. 
This article proceeds as follows. In Part II, I explain the political and social contexts behind the various economic systems adopted through Vietnam's constitution. Part III considers the procedural issues involved in the 2013 Constitution, and how the discourse on the 2013 Constitution spread from internal CPV debates to the wider public. Beyond evaluating the extensive literature on constitutional debates available both in Vietnamese and English, and recorded debates at plenary meeting sessions of the National Assembly (NA), I will analyze the documentation, drafts, explanations, and conference proceedings provided by the Constitution Revision Commission - the most powerful political commission in charge of the revision of Vietnam's constitution. In supporting the work of the Commission, the NA established an Editing Board which prepared the Draft Constitution. In order to learn from their personal experiences and to glean insider perspectives, I have interviewed several key members of the Editing Board, particularly the experts in charge of drafting the provisions relating to Vietnam's economic system. The interviews explain how the Constitution Revision Commission had to respond to the growing demands of the public and the necessary compromises negotiated within the CPV to secure economic growth.

Part IV describes the socio-economic context in which public demands for changes to the economic system have been made. I will also discuss and explain the main platforms of constitutional discourse and emerging themes relating to Vietnam's economic system. To this end, this article focuses on three broad themes: (i) the role of the state versus market in the allocation and distribution of resources; (ii) the role of public versus private property; and (iii) the need to redefine the regulatory functions of the state and to improve the state's effectiveness in responding to rapid economic growth. Part V concludes with some remarks and lessons learned from the discourse on the $20 \mathrm{I}_{3}$ Constitution.

\section{THE ECONOMIC SYSTEM IN VIETNAM'S CONSTITUTIONS}

\section{A. The I946 Constitution}

Vietnam's economic system has experienced continuity and change throughout Vietnam's constitutional history. The 1946 Constitution of the Democratic Republic of Vietnam (I946 Constitution) was adopted at a time when the CPV's power was extremely fragile. Vietnam's newly declared independence was threatened by the Chinese Kuomintang and the French, with the First Indochina War taking place soon after from I 946 to I954. As a survival tactic, the CPV was formally dissolved, and operated under the guise of a Marxist Research Association within the larger nationalistic Viet Minh alliance. This political context explains the economic system adopted by the I946 Constitution. There was no single chapter solely focused on Vietnam's economic system, no concept of a command economy based on state ownership of productive means, no central planning, and no socialist cooperatives in the 1946 Constitution. By contrast, the I936 Constitution of the Union of Soviet Socialist Republics (I936 Soviet Constitution) had already firmly stipulated a socialist command economy. ${ }^{6}$ However, in contrast to the

6. I936 Soviet Constitution, supra note 5, arts 5-I I. See also J Arch GETTY, "State and Society under Stalin: Constitutions and Elections in the I930s" (I99I) 50 Slavic Review I 8. 
Soviet Union's rigid command economy, the 1946 Constitution of Vietnam was much more liberal. It protected private property and recognized a mixed economy, with a public sector replacing the exploitative system used by the former colonial regime, the existence of domestic and foreign private business, and an agricultural society dominated by private farmers. ${ }^{7}$

\section{B. Reception of the Socialist Economic System in the 1959 and 1980 Constitutions}

During the Second Indochina War (I954-I975), as Vietnam was a divided country, the two constitutions adopted by South Vietnam in I956 and I967 were driven by liberal democratic ideals. South Vietnam's constitutions provided for strong protection of private property, a market economy, and business competition. ${ }^{8}$ By contrast, the first ideological indication of North Vietnam's inclination towards a socialist economic order can be seen in Chapter II of the 1959 Constitution of the Democratic Republic of Vietnam (1959 Constitution). ${ }^{9}$ Based on the main ideological concepts provided for in Articles 5 to I I of the 1936 Soviet Constitution, the socialist economic system in North Vietnam, as in all other socialist countries, was subject to the following principles:

(1) The national economy shall be subject to state management, and the socialist state shall entirely control the economy though a rigid central planning system.

(2) The national economy shall be dominated by the state economy sector, owned by the state and operated under direct state control. All industries shall be controlled by state companies.

(3) Freedom of contract, free market, and competition shall be banned, as they are considered as relics of exploitative capitalism and would disrupt the centrallyplanned economy. The distribution of property shall be ordered entirely by the state. The socialist state shall exercise an absolute monopoly over foreign trade.

(4) Private property in the economy shall be eliminated. For this purpose, private property shall be confiscated and transferred into state property. Citizens are not allowed to own productive means, but they are allowed to own individual property but only for consumption purposes.

(5) While industries shall be controlled by state companies, agriculture, handicraft, and trade shall be run by socialist cooperatives in line with the planning system.

All of these main principles were introduced into North Vietnam, particularly under Chapter II of the I959 Constitution. The following provisions are noteworthy: (i) the state shall control the economy through central planning; ${ }^{\text {IO }}$ (ii) the state sector

\footnotetext{
7. $\quad$ I946 Constitution, supra note I, art I 2.

8. I967 Constitution of the Republic of Vietnam (South Vietnam) (adopted I8 March I967), arts I 8-20.

9. $\quad$ I959 Constitution, supra note I, arts 9-2I.

ı. Ibid, art по.
} 
shall dominate the economy; ${ }^{\text {II }}$ and (iii) important natural resources shall be "owned by the entire Vietnamese people" (i.e. by the state). ${ }^{{ }^{2}}$ Interestingly, land was - at least formally - not confiscated, and publicly and privately owned properties survived until I980. However, the I959 Constitution provided that the state would guide farmers and help them to establish agricultural cooperatives. ${ }^{\mathrm{I} 3}$ Private businesses would also be rehabilitated to align with North Vietnam's socialist orientation. This "rehabilitation scheme" was concluded in the I960s for North Vietnam, and repeated in the late r970s in South Vietnam after Vietnam was unified under communist rule. To this end, all private businesses were either transferred or incorporated into state companies, without any compensation.

Following Vietnam's reunification in 1975, extremely extensive provisions on the socialist command economy were included in the 1980 Constitution of the Socialist Republic of Vietnam (I980 Constitution). Borrowing heavily from the I977 Soviet Constitution, ${ }^{\mathrm{I} 4}$ the 1980 Constitution demonstrated Vietnam's commitment towards party-state control over the entire economy through a rigid command system. ${ }^{\mathrm{I} 5}$ Private property was banned, the entirety of Vietnam's land was declared to be state property, and businesses of former feudal landlords and foreign capitalist companies were confiscated without compensation. Private businesses, which only existed in the former South Vietnam, were "rehabilitated" - that is, confiscated without any compensation. ${ }^{{ }^{6}}$ There was no market, no competition, and no freedom of contract under the 1980 Constitution. In essence, the true political agenda of the CPV was to force the adoption of a command economy over the whole of Vietnam à la the Soviet model through the I980 Constitution. While the nuances of the 1959 Constitution remained nationalistic, the wording and style of the 1980 Constitution were purely from a communist revolution agenda.

\section{From Commodity Economy to Socialist-Oriented Market Economy}

Due to the near-collapse of the regime in the late I980s, Vietnam was forced onto the path of reform, which began with the allocation of land plots to individual farmer families, and the gradual rebirth of private business. What is now known as Doi Moi or "renovation" emerged from various fence-breaking policies (phá rào) against the economic system, reflected in Chapter II of the I980 Constitution. This transition began from the bottom up with the policies of provinces, which in turn dismantled, piece by piece, the central command system. Over time, the land lease system in agriculture led to permanent private land use rights; larger private companies emerged from small household businesses, and the piecemeal dismantling of the central planning system gave way to the freedom to conduct business. These initial steps to "test the waters" were taken at the outset of reforms for a so-called "multi-sectoral

\footnotetext{
II. Ibid, art II.

I2. Ibid, art I I-I2.

I3. Ibid, art I4.

I4. I977 Soviet Constitution, supra note 5, arts IO-I 8.

I5. I980 Constitution, supra note I, art 33.

I6. Ibid, arts I5-36.
} 
economy", and were reflected in the 1992 Constitution of the Democratic Republic of Vietnam (I992 Constitution). By preserving the dominant role of the state sector in the economy, the Vietnamese party-state reluctantly tolerated the existence of foreign direct investment, the growing household business and private sectors, and began to gradually accept the freedom to contract and competition. ${ }^{17}$

Vietnam's second decade of reform began with the issuance of the I999 Law on Enterprise. ${ }^{18}$ This piece of legislation initiated a number of far-reaching economic reforms and established substantially more constitutional values than the 1992 Constitution itself. Regarding the state-citizen relationship, for the first time in Vietnamese legal history, the I999 Law on Enterprise provided in its Preamble that the right to do business was part of a citizen's liberties. The state was obliged to abandon cumbersome licensing requirements and procedures, and most importantly, obliged to provide business registration as a public service. Furthermore, state authorities were not allowed to issue regulations which might contradict a citizen's right to do business. ${ }^{19}$ At that time, a common slogan was that "the state is only allowed to do what is strictly limited by the law, while an individual is free to do anything which is not explicitly prohibited by the law". While this approach might seem natural - even obvious - to liberal democracies, it heralded the start of a brand new era for Vietnam, and promised even greater economic and social reforms. Half a million private companies mushroomed as result of the liberalization process that began with the 1999 Law on Enterprise. ${ }^{20}$

The 200 I revision of the constitution documented further ideological compromises adopted by the Vietnamese party-state towards the market economy. Replacing the ambiguous term "multi-sectoral economy", the $200 \mathrm{I}$ revision embraced for the first time the notion of a "socialist-oriented market economy". ${ }^{21}$ The very words "market", "competition", "freedom of contract", and "liberty to legally conduct business" experienced a revival in Vietnamese legal jargon after years of being deemed as disruptive elements against socialism. The story of Vietnam's second decade of reform essentially involved a step towards markets in the relationship between the state and the market, a step towards private property in the relationship between private and public property, and a step towards liberty in the relationship between state dictatorship and democracy.

The 20I3 Constitution was expected to lead the country into the next wave of institutional reform. The economic system and the entire 20I3 Constitution can only be explained and understood within Vietnam's changing economic, political, and social contexts. As with the Chinese Communist Party, the CPV entered into a great

I7. I992 Constitution, supra note I, arts I 5 (multi-sectoral economy), I9 (dominant role of state sector), and 2 I (allowing household and private businesses).

I 8. I999 Law on Enterprise (adopted I2 June 1999) [ I999 Law on Enterprise].

I9. Ibid, arts 7 (rights of enterprise) and I 2 (business registration procedures).

20. The updated number of registered companies, partnerships and household businesses can be downloaded from the website of Vietnam's Business Registration Authority: News and Updates, online: National Business Registration Portal <https://dangkykinhdoanh.gov.vn/NewsandUpdates/ tabid/I05/CategoryID/52/language/en-GB/Default.aspx $>$.

2I. 1992 Constitution (200I Rev), supra note 2 , arts I 5-29, particularly arts ${ }_{5}$ (socialist oriented market economy), I 6 (recognition of domestic capitalist sector, freedom to competition equally before the law), 2I (no limitation of size and scope of private sector), and 57 (freedom to conduct business). 
political experiment by embracing capitalist market rules, stalling political reform, and preserving the political monopoly of the Party. The decades of transition towards a market economy unleashed, possibly unexpectedly, many social forces, which forced the CPV to make various compromises. Diverse platforms, debates, and exchanges sharpened the awareness of constitutional values; these phenomena are quite unique. Arguably, the instrumentalist approach should no longer be the dominant approach taken towards understanding socialist constitutions, particularly in the case of Vietnam and China.

Although the constitution remains part of the CPV's political agenda, it has taken on a new life as a social compromise, or a social contract reflecting a changing society in transition. Under these circumstances, the CPV has moderated and controlled constitutional dialogue, but it was also forced to respond to the steadily growing demands of new stakeholders and forces within the party-state and beyond, particularly from the private sector, emerging civil society, and vibrant social media. ${ }^{22}$ All these diverse forces have contributed to determine the political reform agenda of the CPV. ${ }^{23}$ Being pushed to accept one ideological compromise after another, the CPV can no longer consider the constitution as its mere political tool. Constitutional debates, as in the case of Vietnam, appear to be useful and practical vehicles, and may create liberties which can transform Vietnam's Leninist dictatorship towards a flexible CPV-controlled authoritarian regime. In this sense, the 2013 Constitution is not a purely socialist constitution under the traditional approach. It is a small step towards liberal reforms. A non-dichotomous view is warranted here: just as illiberal democracies do exist in the "liberal" West, ${ }^{24}$ there might also be strains of "quasi-liberal" values in the constitutions of "authoritarian" transitional countries. The $20 \mathrm{I}_{3}$ Constitution therefore contains the seeds of future political and legal guarantees which would, or at least could, protect individual liberties. We may call this the "transitional role of the constitution" in a socialist transformation towards democracy.

\section{THE SOCIO-ECONOMIC AND POLITICAL CONTEXTS OF CONSTITUTIONAL DEBATES ON THE ECONOMIC SYSTEM IN VIETNAM}

Economic performance is crucial to the legitimacy of the CPV as the sole ruling party in Vietnam. The Party was forced to accept innovative fence-breaking policies from the provinces, thus initiating the first wave of economic reform in the late I980s, since the near-collapse of the national economy seriously threatened the regime's existence. ${ }^{25}$

22. BÙI Hải Thiêm, "Pluralism Unleashed: The Politics of Reforming the Vietnamese Constitution" (20I4) 9(4) Journal of Vietnamese Studies I.

23. Zachary ABUZA, Renovating Politics in Contemporary Vietnam (London: Lynne Rienner Publishers, 2OOI) at 75-I3I.

24. Fareed ZAKARIA, The Future of Freedom: Illiberal Democracy at Home and Abroad (New York: W W Norton \& Company, 2007) at 89-II9.

25. DAO Xuan Sam, "Những Bước Đường Đổi Mới Chuyển Sang Nền Kinh Tế Thị Trường (I979-2007) [The Doi Moi Process towards a Market Economy (1979-2007)]” in DAO Xuan Sam \& VU Quoc Tuan, eds, Renovation in Vietnam: Recollection and Contemplation (Hanoi: Tri Thuc Publishing House, 2008). 
Without reform, the CPV's survival would have been challenged. This threat is well recognized by the CPV, with "economic backwardness" being considered as the primary threat to the socialist regime in the CPV's political jargon. ${ }^{26}$

In retrospect, the CPV has managed to survive and maintain social support in order to strengthen its legitimacy. Undoubtedly, Vietnam's three decades of reforms have made it a success story. As several scholars have noted: "[F]rom I986 to 20I5, the economy has grown at an average rate of $6.5 \%$ per year. Given the fact that since World War II, only I3 countries have been able to sustain an average growth rate of $7 \%$ or more for 30 consecutive years, Vietnam's economic performance is quite impressive." ${ }^{27}$ Vietnam has risen from the ranks of the world's poorest nations to join the lower-middle income group. Tens of millions of Vietnamese have escaped poverty, and most Vietnamese have shared the fruits of economic reform.

However, since 2008, Vietnam has faced an economic slowdown and serious socio-economic and political challenges. From 2008 to 2014 , Vietnam's economy grew at only $5.4 \%$ per year, a marked decrease from $8 \%$ in 2007 . Chronic weakness and difficulties seriously threatened macroeconomic stability.

After the country celebrated its accession to the World Trade Organization (WTO) in early 2007, the Vietnamese party-state had to deal with serious economic turbulence. Public debts increased and the efficiency of public investment worsened. ${ }^{28}$ The public sector, mainly controlled by about 6,000 state-owned companies, was highly inefficient, and numerous large state business groups, notably the Vietnam Shipbuilding Industry, became insolvent. ${ }^{29}$ The domestic private sector comprising nearly half a million private companies has been shrinking, with an alarming number of enterprises closing. ${ }^{30}$ Domestic firms could not develop in size; they remained as very small family businesses, and failed to become value-added

26. The Party called it the "comprehensive social and economic crisis". See Communist Party of Vietnam, Strategy for Socio-Economic Development (adopted at the 7th Party Congress: June I99I). The CPV's midterm National Congress held on 20-25 January 1994 identified four threats to the socialist regime, including: economic backwardness, "corruption and social evils", socialist diversion, and "peaceful evolution of the hostile forces”. Báo Điện tử Đảng Cộng Sản Việt Nam [Communist Party of Vietnam Online Newspaper], "Văn kiện Đảng [Party’s Documents]", online: Communist Party of Vietnam Central Committee <http://dangcongsan.vn/tu-lieu-van-kien/van-kien-dang/van-kien-dai-hoi. html $>$.

27. VU Thanh Tu Anh et al, "Institutional Reform: From Vision to Reality" (Policy discussion paper prepared for the Vietnam Executive Leadership Program, Harvard Kennedy School, I3-I7 April 20I 5), online: <http://www.fetp.edu.vn/en/policy-papers/discussion-papers/institutional-reform-from-visionto-reality/>.

28. "The Structural Roots of Macroeconomic Instability" (Policy discussion paper prepared for the Vietnam Executive Leadership Program, Harvard Kennedy School, 9 September 2008), online: <http:// www.fetp.edu.vn/en/policy-papers/discussion-papers/policy-discussion-no3-the-structural-roots-ofmacroeconomic-instability/>.

29. VŨ Thành Tự Anh, "WTO Accession and the Political Economy of State-Owned Enterprise Reform in Vietnam” (Working Paper, University of Oxford, The Global Economic Governance Programme) (GEG WP 2014/92) (October 2014).

30. PHAM Duy Nghia et al, "Unplugging Institutional Bottlenecks to Restore Growth" (Policy discussion paper prepared for the Vietnam Executive Leadership Program, Harvard Kennedy School, 26-30 August 20I3), online: <http:/www.fetp.edu.vn/en/policy-papers/discussion-papers/unplugging-institutionalbottlenecks-to-restore-growth/>. 
businesses in the global value chain. ${ }^{3 \mathrm{I}}$ The agricultural sector has been shrinking as well. Investment in agriculture decreased, and productivity in the agricultural sector remained extremely low compared to Vietnam's Southeast Asian neighbours. ${ }^{32}$ The banking sector faced difficulties: lack of transparency and inefficiency in governance, caused by multiple crossholding of shares, led to an increase in bad debts and insolvency. ${ }^{33}$ Speculative investment in land and housing projects pushed land prices to very high levels as compared to the average per capita income. Double-digit inflation rates threatened to return, and the Vietnamese dong was devalued. This macroeconomic instability became a serious problem for the CPV in late 2008. However, it should be noted that within this economic landscape, only the foreign direct investment sector was stable, and steadily grew in size and number. The proportion of foreign direct investment in Vietnam's total exports has increased significantly over the years.

Vietnam's macroeconomic instability appears to be deeply rooted in its inadequate institutional and legal framework. ${ }^{34}$ Given that state companies were intended to take a dominant role in Vietnam's economy, they were often preferred over domestic private companies. Despite their favourable access to land, natural, and financial resources, state companies failed precisely because of inefficient management and lack of competitiveness. Inefficient public service, cumbersome administrative procedures, lack of efficient contract enforcement, and endemic corruption had a serious effect on the local business environment. There was substantial uncertainty over land ownership, particularly when the 20-year leases provided by the 1993 Land Law were expected to end in $20 \mathrm{I}_{3}$, such that there was a real risk that corrupt government officials might expropriate land without just and fair compensation. This, in turn, reduced investment levels in agriculture. ${ }^{35}$

In addition to these widely acknowledged economic challenges, Vietnam has also faced challenges from a rising and assertive China and increasing public expectations for economic development and civil freedoms since 2008. The rise of China has created serious economic, social, and political challenges for Vietnam and the CPV. From 1978 to 2008, Vietnam only achieved a modest 5.4\% Gross Domestic Product growth rate, while China achieved a much higher average growth rate of $10 \%$. If China and Vietnam had the same income per capita during the I970s, China's income

3I. Tu-Anh VU-Thanh, "The Political Economy of Industrial Development in Vietnam: Impact of State-business Relationship on Industrial Performance, I986-20I2" (Working Paper, United Nations University, World Institute for Development Economics Research) (WIDER Working Paper 20I4/I 58 ) (December 2OI4).

32. John KEYSER, Steven JAFFEE \& Tuan Do Anh NGUYEN, "The Financial and Economic Competitiveness of Rice and Selected Feed Crops in Northern and Southern Vietnam" (Working Paper, World Bank) (Report No $\mathrm{ACS}_{4325}$ ) (January 2013) at 33.

33. Jonathan PINCUS et al, "Structural Reform for Growth, Equity, and National Sovereignty" (Policy discussion paper presented at the Vietnam Executive Leadership Program, Harvard Kennedy School, I3I7 February 20I2), online: <http://www.fetp.edu.vn/en/policy-papers/discussion-papers/structuralreform-for-growth-equity-and-national-sovereignty/>.

34. Khong M VU, “The Institutional Root Causes of the Challenges to Vietnam's Long-Term Economic Growth" (2014) I3(I) Asian Economic Papers I 59.

35. DANG Hoa Ho \& Malcolm MCPHERSON, Land Policy for Socioeconomic Development in Vietnam (Cambridge, MA: Harvard Kennedy School and Institute of Policy and Strategy for Agriculture and Rural Development, 2010). 
per capita has risen significantly since its accession to the WTO. It is now 2.5 times more than that of Vietnam. ${ }^{36}$ For Vietnam, and the rest of the world, China has been nursing a strong desire to impose changes in the region and the world. With rising tensions in the South China Sea, Vietnam must maximize its efforts to boost its growth and strengthen its economic potential to fend off challenges from China's economic dominance. Undoubtedly, the CPV's legitimacy as the ruling party will be questioned if it cannot provide strong leadership to protect Vietnam's sovereignty.

Finally, there is significant social pressure to restore high economic growth rates. Since 2008, as Vietnam has become more integrated with the outside world, both the business conmunity and the public at large have sensed that Vietnam's economy is lagging relative to others in the region. If the economy continues to stagnate, causing Vietnam to lag further behind, the public will eventually lose their patience, and the Vietnamese government and the CPV will suffer from diminished legitimacy.

In responding to these socio-economic and political challenges, the CPV is under pressure to redefine Vietnam's growth model. Instead of relying on exploiting natural resources (exporting crude oil and minerals) and labour-intensive industries (manufacturing and assembling), Vietnam has to find ways to adopt a competitive, dynamic, and innovative economic growth model. Critical voices demanding changes in the economic growth model have become louder since 2008. ${ }^{37}$ Domestic pressures have grown, and are calling for deeper and comprehensive institutional reform, especially on disciplining state-owned companies, imposing strict constraints on public investment, and promoting the private sector as a new engine of the economy.

In this context, the CPV became aware of the need to revise the I 992 Constitution in 2008. From 2009 to 2010 , public discussions primarily focused on Vietnam's economic growth model and institutional reform. As the supreme organ within the Party apparatus, the $\mathrm{II}^{\text {th }}$ Party Congress adopted the Socio-Economic Development Strategy for Vietnam in January 20II for $20 \mathrm{II}$ to $2020.3^{3}$ In this document, institutional reform was identified as the first among the three proposed policy priorities. The document also provided that the 1992 Constitution was to be revised. The I I ${ }^{\text {th }}$ Party Congress elected a Central Committee, a body with 175 official and 25 alternate-members. From 201 I to 2016 , this Central Committee would be in charge of implementing the institutional reform as envisaged by the I I $^{\text {th }}$ Party Congress. ${ }^{39}$

36. Vu et al, "Institutional Reform", supra note 27.

37. Vietnam 2035: Toward Prosperity, Creativity, Equity, and Democracy (Washington DC and Hanoi: World Bank and the Ministry of Planning and Investment, 2016) at I2-I3.

38. The I Ith Party Congress was held on I I-I9 January 20I I. The political documents adopted at this I Ith Congress are available at Communist Party of Vietnam Online Newspaper, supra note 26.

39. Note that only 175 official members of the Central Committee are entitled to vote. The 25 alternatemembers are entitled to participate in all discussions, but they are not entitled to vote. The Central Committee elected a Politburo with I 4 members at the I Ith Party Congress in January 20I I. The number of members of the Politburo increased to I6, as two additional members were elected at 7 th Central Committee's Plenums held on 2-I I May 20I3. The next I 2th Party Congress is scheduled for early 2016. From 20 I I to June 20I 5 , the Central Committee held I I Plenums. The revision of I 992 Constitution was debated at several plenums, including the 2nd Plenum held on I-IO July 20II, the 6th Plenum on I-I 5 October 20I2, and the 7 th Plenum on 2-I I May 2013. 


\section{DYNAMICS LEADING TO CONSTITUTIONAL CHANGE: THE DEBATES ON ECONOMIC REFORM}

Among the three constitutional revisions in Vietnam in I992, 200I, and 20I3, the 2013 revision witnessed the most lively and controversial debates. As reported by the Constitution Editing Board, from 20II to 20I3, 28,000 workshops and conferences were held countrywide. In an unprecedented move by the Vietnamese government, millions of copies of the Draft Constitution were printed and disseminated to individual households, and residents in both urban and rural areas were asked to give their comments and suggestions to the heads of their residential areas. ${ }^{40}$ From villages, wards, communes, and districts, all local administrations, public institutions, and associations within the Vietnamese political system were obliged to collect comments from citizens on the Draft Constitution. As a result, some 26 million opinions were collected and reported. ${ }^{4 \mathrm{I}}$ Together with the extensive coverage in the state-controlled media, vibrant and sometimes controversial discussions took place through social media. ${ }^{42}$ From these unique circumstances, numerous questions may be raised. First, did the CPV intend for this constitutional dialogue to take place, and why did these discussions occur? Second, how were these discussions received by the public? Finally, which constitutional values dominated these discussions?

Various long-standing social dynamics have nurtured the exchange of ideas and debates on constitutional values in Vietnam, and they have continued to influence public discourse following the promulgation of the 2013 Constitution. These dynamics existed long before the first step of the revision procedures started in July 20I I. Three of these dynamics will be discussed, namely:

(1) the internal discussions within the party-state apparatus seeking an alternative economic growth model for Vietnam;

40. In Ho Chi Minh City, for example, 2.6 million copies of the Draft Constitution were disseminated in March 20I3 to households for feedback. See People Council of Ho Chi Minh City, Báo cáo số I $50 / B C$ BCĐTPHCM ngày $3 I_{1 / 3 / 20 I 3}$ về Tổng hợp ý kiến nhân dân thành phố Hồ Chí Minh về Dự thảo sửa đổi Hiến pháp năm 1992 (Đợt 2: từ ngày 06 tháng 03 dến ngày 26 tháng 03 năm 2013) [Report No I $50 / B C$ BCDTPHCM on Collection of Ho Chi Minh City's Citizen on the I992 Constitution Amendment Draft (Second Phase, from 6 March to 26 March 2013)] (3 I March 2013), online: HCM City People Council $<$ http://www.dbnd.hochiminhcity.gov.vn/web/guest/cac-van-ban;jsessionid=73FCA $78 \mathrm{AAO}_{2} 64 \mathrm{IAA}_{7}$ CFIF2D9987EDEFI?p_p_id=EXT_ARTICLEVIEW \&p_p_lifecycle=o\&p_p_col_id=column-right \& p_p_col_count=3\&_EXT_ARTICLEVIEW_groupId=I 02 I $7 \&$ \&XT_ARTICLEVIEW_articleId= 5I9568_EXT_ARTICLEVIEW_version= I.o\&_EXT_ARTICLEVIEW_redirect $=\%$ 2Fweb $\%$ 2Fguest $\%$ 2Fbai-viet-tham-khao $>$.

4I. Constitution Revision Committee, BÁO CÁO Một số nội dung cơ bản giải trình, tiếp thu, chỉnh lý Dự thảo sửa đổi Hiến pháp năm I992 trên cơ sởy kiến của nhân dân và của các vị đại biểu Quốc hội [Report on some explanation, reflection, and modifications on the 1992 Constitution Amendment Draft, based on comments of citizen and of members of the National Assembly] ( I 7 October 20I3), online: Library of the National Assembly <http://duthaoonline.quochoi.vn/DuThao/Lists/DT_DUTHAO_NGHIQUYET/ View_Detail.aspx?ItemID=32>.

42. The most comprehensive documentation the debate on the $20 \mathrm{I}_{3}$ Constitution is available online at Tài liệu sửa đổi Hiến pháp [Documentation to Constitution Revision] (26 February 20I4), online: Library of the National Assembly <http://duthaoonline.quochoi.vn>. The Report presented by the Constitution Drafting Board alone runs to over 800 pages. In addition, there are extensive reports provided by the government, by the Fatherland Front, by the Supreme Court, and by the Supreme Procuracy. Rich sources of video and other records are also available online. They include reports from lively debates among members of the NA in plenary meetings sessions and controversial dialogues at workshops and meetings. 
(2) the diversity of interests within Vietnam's fragmented political system, representing different concerns and priorities relating to the economic system; and

(3) the growing expectations of the public, who are pushing for substantial institutional reform to accelerate economic growth.

\section{A. Debates Within the Party-state Apparatus on an Alternative Growth Model}

With institutional reform as the most pressing policy priority for economic growth, the I I $^{\text {th }}$ Party Congress held in January 20 I I envisaged that the 1992 Constitution would be revised as part of a comprehensive institutional reform project. The "orientation" of the proposed revision was clarified at the $2^{\text {nd }}$ Plenum of the Party Central Committee in July 20I I. ${ }^{43}$ In August 20I I, the Constitution Revision Commission was established to draft the necessary revisions. ${ }^{44}$ To support the work of the Commission, a team of 43 experts from various areas including law, economics, and sociology, was appointed to the Editing Board. ${ }^{45}$

The most important concern for the CPV leadership was to control the entire revision process. There was a possibility that the resulting constitutional discussions would escape the CPV's control, leading to public demands for further political changes. The scope of revision, topics of discussion, and even the personnel involved had to be approved by the CPV's top leadership. 28 out of 30 members of the Constitution Revision Commission were members of the CPV's Central Committee, and 8 of them were also members of the Politburo; effectively, half of the Politburo participated in the Commission. ${ }^{46}$ The Commission was therefore the highest political collective in the country and was authorized by the Politburo to determine the scope and content of the proposed revisions.

The Editing Board was also carefully selected and approved by the CPV. Notably, the majority of these experts were legal scholars who had studied socialist legal systems

43. Party documentations are available at "Communist Party of Vietnam Online Newspaper", online: Communist Party of Vietnam Central Committee <http://en.dangcongsan.vn/>.

44. Resolution 06/20I I/QHI3 on the formulation of the Constitution Revision Commission adopted by the National Assembly, dated 6 August 20I I. In retrospect, the number of members on the Commission increased and changed over time. The 1946 Constitution was drafted by a 7 -member Commission chaired by President Ho Chi Minh ( 3 Communists, 4 Non-Communists). In 1957, a drafting commission with 28 members headed by Ho Chi Minh was established, in charge of drafting the 1959 Constitution. In I976, a Commission with 36 members, chaired by President Truong Chinh, was established to draft the I980 Constitution. The 1992 Constitution was drafted by a I 6-member Commission chaired by President Vo Chi Cong. The 200 I revision was drafted by a 22-member Commission chaired by President Nguyen Van An. The 2013 Constitution Revision Commission had 30 members. Further, the 2001 revision was drafted within only one year, but the $20 \mathrm{I}_{3}$ Constitution was drafted in 3 years from $20 \mathrm{II}_{\mathrm{I}}$ to $20 \mathrm{I}_{3}$.

45. Resolution 03/NQ-UBDTSDHP adopted by the Constitution Revision Commission to create the Constitution Revision Editing Board, dated 23 August 20II. The Editing Board is divided into 6 teams, with each team in charge of drafting one or more Chapters of the Draft Constitution.

46. The Constitution Revision Commission was established by the NA and chaired by the NA President, Politburo member Nguyen Sinh Hung. The other 7 Politburo members attending the Commission were: Madame Tong Thi Phong (Vice NA Chairwomen), Mr Le Hong Anh (Chair of Party Secretariat), Mr Dinh The Huynh (Chair of Party Ideology \& Culture Committee), Mr To Huy Rua (Chair of Party Personnel Committee), Mr Nguyen Xuan Phuc (Vice Prime Minister), Mr Phung Quang Thanh (Minister of Defence), and Mr Tran Dai Quang (Minister of Public Security). 
in former socialist states during the late I970s. $^{47}$ The remaining members were representatives from the CPV's academies, public securities academies, social and natural scientists, economists, and one historian. ${ }^{48}$ This Editing Board was responsible for conducting needs assessments, evaluating and responding to comments and suggestions from the public, and preparing the drafts presented to the Commission for approval. Consequently, the most interesting constitutional discussions occurred within the Editing Board. The academic backgrounds of the Editing Board members evidently played a role. When debates became heated and controversial, especially on topics such as "the entire people's ownership of the means of production", the members fell back on concepts and practices they were familiar with. ${ }^{49}$

Beyond controlling the selection of personnel participating in the revision process, the CPV also exerted tight control over the revision process as a whole. In August 20 I , the NA proposed that the revision process should be conducted from August 20 I I to November 2013 and include I 2 major stages. ${ }^{\circ}$ At each stage, a rigid reporting system that promoted accountability would be implemented. For instance, during the first stage, the Politburo was in charge of deciding the basic guidelines, instructions, and the scope of the revision. During the fifth stage in June 20I 2, the Politburo was responsible for approving the initial draft presented to the Central Committee for consideration. The Politburo also preserved the power to make final decisions on controversial topics. ${ }^{5 \mathrm{I}}$ This entrenched the CPV's control over the entire revision process.

However, the CPV as a political organization lacked a single united view as to the proposed revisions. It would be naïve to expect the CPV to act with one mind and one voice. Rather, as a national political organization with 3.6 million members, the CPV is an apparatus. Individual members and internal organizations within this apparatus have different concerns and interests. The heated debates between "progressive" and "conservative" factions over the alternative economic growth models occurred within the Party apparatus before and during the I I ${ }^{\text {th }}$ Party Congress in early $20 \mathrm{II}$, and these continue to influence socio-economic and political discourse in Vietnam today.

The "progressive" faction of the CPV pushed for the market to play a greater role in the allocation and redistribution of economic resources. They also advocated for Vietnam to take steps towards deeper and more comprehensive integration into the global economy. Bilateral and regional free trade agreements, together with negotiations

47. 22 of these legal scholars had been educated in the former Soviet Union, and the remaining 2 were educated in East Germany.

48. The Editing Board was chaired by Phan Trung Ly, Chairman of NA Law Committee. The board operated with support from NA Law Committee staff, led by NA member Le Minh Thong, and some staff from the NA Legislative Academy. The three economists on the Editing Board are Tran Xuan Ba (CIEM: Central Institute for Economic Management), Tran Dinh Thien (VASS: Vietnam Academy for Social Science) and NA member Tran Du Lich (Ho Chi Minh City). The only non-Party member on the Editing Board is the historian, NA member Duong Trung Quoc. For a comprehensive list of members on the Editing Board, see Resolution 03/NQ-UBDTSDH, supra note 45.

49. Personal interviews with Prof Dao Tri Uc (Vietnam National University Law School) and Prof Mai Hong Quy (Ho Chi Minh City Law University), members of the Editing Board, Ho Chi Minh City, Vietnam ( 8 June 20I5).

50. See Proposal No I I/TTr/UBTVQHi 3 dated August 02, 20 I I, prepared by the NA Standing Committee.

5I. Personal interview with Mr Le Minh Thong, NA member, Vice-Chair of NA Law Committee, Vice-Chair of the Constitution Editing Board, Harvard Kennedy School, United States of America (I3 April 201 5). 
over the Trans-Pacific Partnership (TPP), have exerted significant external pressure on Vietnam for the adoption of a market economy. The "progressive" faction of the CPV therefore pushed for greater certainty in property law, stronger protection of private property, especially land, and reforms of the state apparatus to improve the business environment. They also called for Vietnam to recognize the private sector as the new engine of the national economy, and to ensure competition and equality among diverse economic sectors. ${ }^{52}$ To this end, they argued that state intervention in economic matters should be restricted to only what was necessary, such that the allocation and redistribution of resources would be dealt with by the market. Both privately and publicly owned firms would be subject to market discipline. ${ }^{53}$

On the other hand, the "conservative" faction of the CPV advocated defending the traditional socialist system. ${ }^{54}$ They feared that the Vietnamese party-state would not be able to preserve its monopoly over society, particularly with respect to its control over the economy, if most of Vietnam's means of production were privately owned. The "conservative" faction of the CPV therefore defended the concept that "the means of production shall be owned by the entire Vietnamese people" and the dominant role of State-Owned Enterprises (SOEs). They also focused on the state's control and management of the national economy according to socialist principles. Land and natural resources would be publicly owned, and the state would have the right to acquire land where necessary, especially to "modernize" the country. ${ }^{55}$ For them, Vietnam's "socialist orientation" should be emphasized in its economic order.

This debate on Vietnam's alternative growth models also gives an indication of the changing political power structure within the CPV apparatus. Intensive political infighting seems to be common in authoritarian regimes, and change in socialist countries only appears to be possible after the death of political strongmen. ${ }^{56}$ In

52. Such views were expressed in the Prime Minister's New Year Message 2013, and in the discussions of $\mathrm{Mr}$ Tran Du Lich (Ho Chi Minh City) and Mr Vo Hong Phuc (Minister for Planning and Investment) at the I Ith Party Congress. See MINH Thúy, "Thảo luận văn kiện Đại hội và tâm tư của một vị bộ trưởng [Discussion of the Party's Documents and Reflections of a Minister]", VnEconomy (I4 January 20II), online: VnEconomy <http://vneconomy.vn/thoi-su/thao-luan-van-kien-dai-hoi-va-tam-tu-cua-mot-vibo-truong-20I IOI I $308425366 \mathrm{I}$.htm $>$.

53. Personal interviews with Tran Dinh Thien (Director of VASS: Institute for Economic Research) and Tran Huu Huynh (President of VIAC: Vietnam International Arbitration Center, former director of VCCI Legal Department), members of the Editing Board, Ho Chi Minh City, Vietnam (Io June 20 I 5 ).

54. See e.g. a recent article by Le Xuan Tung, a former Politburo member and Party Secretary of Hanoi on 5 June 20I5, available at: <http://www.qdnd.vn/qdndsite/vi-vn/6I/43/chong-dien-bien-hoa-binh/phaichang-kinh-te-tu-nhan-la-nen-tang-cua-nen-kinh-te-quoc-dan/362757.html $>$.

55. See e.g. the Resolutions at I4th Plenum of Central Committee in December 20Io (adopted with only $55.6 \%$ support for the proposition that the Vietnamese economy should be based on the "dominance of public productive means", as proposed by the General Secretary of the CPV). Further, see the discussions of Le Huu Nghia, President of Party Academy, and Vu Duc Huy, Secretary of SOEs Party Organization at the I Ith Party Congress. After two days of debate at the I Ith Party Congress, the emphasis on the "dominance of public productive means" in the Resolutions was deleted and replaced by the notion of “appropriate productive means". See MINH Thúy, "Vấn đề chưa rõ thì chưa nên đưa vào văn kiện [Unclear Issues Should Not be Incorporated into the Party's Document]", VnEconomy (I4 January 2OII), online: VnEconomy <http://vneconomy.vn/thoi-su/van-de-chua-ro-thi-chua-nen-dua-vao-vankien-20I IOI I 4055 I 3 I 20. htm $>$.

56. Changes only occurred in the former Soviet Union after the death of Stalin, and changes only took place in China after the death of Mao Zedong. Reforms took place in Vietnam in 1986 only after the death of Party Secretary Le Duan. 
Vietnam's case, the passing of the first generation of revolutionaries has effectively removed these strongmen, ${ }^{57}$ and the CPV's current leadership is a collective one with every Politburo member having a de facto veto right. ${ }^{5}$ If the General Secretary fails to demonstrate strong leadership and influence, politically and economically, the power structure within the CPV could change. From 200I to 20I I, Nong Duc Manh, a Vietnamese citizen from the Tày ethnic minority, was elected as the General Secretary of the CPV. During his two terms in office, the management of Vietnam's economy was shifted from the CPV to the government. The CPV's Central Economic Commission was dissolved. The government was authorized to initiate a nationwide experiment with large state-owned business groups, each comprising hundreds of affiliated companies throughout the country. ${ }^{59}$ The Prime Minister was placed in charge of overseeing I2 large national business groups. ${ }^{60}$ Without any accountability mechanism, it is unsurprising that all of these state-owned business groups operated inefficiently, and some quickly went bankrupt.

After the I I $^{\text {th }}$ Party Congress, the newly-elected General Secretary Nguyen Phu Trong attempted to restore the CPV's control over the economy from 20 I I to 20 I 2. The CPV leadership decided to halt its experiment with large state-owned business groups, and pushed for a restructuring program on the governance of SOEs. ${ }^{6 \mathrm{I}}$ The CPV also restored its Central Economic Commission, in the hope that the Commission would help to effectively review the economic policies presented by the government. ${ }^{62}$ The Party Secretary replaced the Prime Minister in chairing the National Commission to Combat Corruption, and the Central Commission of Internal Affairs was also restored. ${ }^{63}$ While not every attempt by the present General Secretary to return control over the economy to the CPV has been successful, economic and political power is being consolidated among the CPV's top leadership. ${ }^{64}$ Political infighting among CPV members also intensified in the lead-up to the $12^{\text {th }}$ Party Congress in early $2016 .{ }^{65}$

57. Such revolutionaries include Ho Chi Minh, Le Duan, Truong Chinh, Pham Van Dong, and Vo Nguyen Giap.

58. VU Thanh Tu Anh et al, "A Retrospective on Past 30 Years of Development in Vietnam" (Policy discussion paper prepared for the World Bank report on Vietnam 2035, 201 5 ) [unpublished].

59. Such groups are also called state incorporations or conglomerates (tập đoàn kinh tế nhà nước).

6o. The I 2 national SOEs included Vietnam Petroleum (PVN), Vietnam Electricity (EVN), Vietnam Coal and Mineral Industries (Vinacomin), Vietnam Airlines (VNA), Vietnam Shipbuilding Industries (Vinashin), Vietnam Textile Industries (Vinatex), and Vietnam Post and Telecommunication (VNPT).

6I. Resolution 50-KL/TW adopted by the Central Committee on restructuring of state-owned business groups and enterprises, dated 29 October 2012.

62. Decision I60/QD-TW made by the Central Committee on establishment of the Central Economic Committee, dated 28 December 2012.

63. Ibid. See also TRAN Cham, "Central Committee of Internal Affairs begins operating from February", Vietnamnet Bridge (4 February 20I3), online: Vietnamnet Bridge <http://english.vietnamnet.vn/fms/ government $/ 65805 /$ central-committee-of-internal-affairs-begins-operating-from-february.html $>$.

64. LE Hong Hiep, "Power shifts in Vietnam's political system", East Asia Forum (5 March 20I5), online: East Asia Forum <http://www.eastasiaforum.org/20I 5/03/o5/power-shifts-in-vietnams-politicalsystem/>.

65. Jonathan LONDON, "Vietnam: Open Secrets on the Road to Succession", cogitASIA (20 January 20I 5), online: Center for Strategic \& International Studies <http://cogitasia.com/vietnam-open-secrets-on-theroad-to-succession/>. 
Presently, the discussion continues as to how the Party will preserve its economic and by extension, political - legitimacy. There is a divergence of views. The tension between the "conservative" and "progressive" factions of the CPV is not purely ideological, and it indicates a deeper change in Vietnam's power structure. The CPV's internal discussions on the role of the state versus the market, public versus private property, and restoring a strong central state to intervene effectively in economic management versus redefining the regulatory functions of the state as a facilitator of economic growth clearly have had a serious impact on the constitutional discourse on Vietnam's economic system.

\section{B. Diversifying Interests within Vietnam's Political System}

After its first meeting in September 20I I, the Editing Board was divided into 6 working teams, and began to evaluate the implementation of the 1992 Constitution and identify areas for revision. Nguyen Van Phuc led the team responsible for the provision on the economic system. ${ }^{66}$ From September 201 I to March 20I 2, numerous workshops and conferences were held, accompanied by extensive media coverage. This raised public awareness on the constitutional roots of economic growth and performance in Vietnam.

Within Vietnam's political system, the government took the lead in conducting needs assessments for constitutional revisions. ${ }^{67}$ This took the form of a nationwide political campaign, in which the CPV led and moderated a broader public discussion. This employed a wide range of forums and platforms within the political system to exchange views and ideas on the proposed revision of Vietnam's economic order in the 2013 Constitution.

In contrast to the constitutional discourse in $200 \mathrm{I},{ }^{68}$ there was a significant divergence of interests within Vietnamese society, thereby intensifying social tensions. Due to the ongoing decentralization of state power in Vietnam, the provinces and large state-owned business groups were able to exert significantly more influence in the policy-making process. ${ }^{69}$ Provinces demanded more autonomy in order to cope with local challenges arising from urbanization and industrialization. In particular, these provinces wanted more autonomy to decide on budgets and to choose the appropriate municipal government model. ${ }^{70}$ At the same time, interest groups and oligarchies

66. Mr Nguyen Van Phuc is an NA member (Vice Chair of NA Economic Committee). Other participants include Prof Tran Dinh Thien (Director of VASS-Institute for Economic Research), Mr Tran Du Lich (NA member, economist), Mr Tran Huu Huynh (VIAC President, former Director of VCCI Legal Department), and Prof Nguyen Nhu Phat (Director of VASS-Institute of State and Law). Personal interviews with Tran Dinh Thien and Tran Huu Huynh, Ho Chi Minh City, Vietnam (Io June 20I 5 ).

67. Decision I695/QD-TTg of the Prime Minister, to establish the Steering Committee to evaluate the implementation of the 1992 Constitution, dated 28 September $201 \mathrm{I}$. This Committee operated from 20 I I to January 2014.

68. Sidel, "Analytical Models", supra note 3.

69. World Bank, Vietnam Development Report 20I0: Modern Institutions (January 20Iо), online: $<$ http://documents.worldbank.org/curated/en/6I 895 I 46832996408 o/Vietnam-development-report2010-modern-institutions $>$.

70. Asia Foundation, "Municipal Government in Vietnam: The Cases of Ho Chi Minh City and Da Nang” (20I3), online: Asia Foundation <https://asiafoundation.org/resources/pdfs/MunicipalGoverment Vietnamese.pdf $>$. 
benefiting from the monopoly of large SOE groups emerged and expanded their influence over the policy-making process. ${ }^{7 \mathrm{I}}$ Ideological doctrines, such as "the entire people's ownership of productive means", the leading role of SOEs and of the state sector, and the role of the state in the management and control over the market, may be used to disguise the interests of well-connected crony businesses. ${ }^{72}$ Supporters of Vietnam's "socialist orientation" do not only include orthodox ideologues, but also groups with vested interests and monopolistic oligarchies, which have exploited the uncertainty of this concept for their own benefit. ${ }^{73}$

From the CPV's internal discussions to public debates, the controversy over the role of the state versus the market, the ambiguity of the concept of "the entire people's ownership of productive means", and the need to redefine Vietnam's "socialist orientation" have dominated the present debate on Vietnam's economic system. Representatives from all sides have articulated their views, from conservatives defending the dominance of public ownership and a strong state sector ${ }^{74}$ to progressives calling for a new orientation towards a facilitative, enabling state. ${ }^{75}$ Leading economists in Vietnam, such as Nguyen Dinh Cung $^{76}$ and Tran Dinh Thien, ${ }^{77}$ have publicly called for a liberal system, with the private sector as the engine of growth. They have argued for reducing the role of the state as the main actor in the economic sphere, limiting it as an economic regulator.

Senior politicians and state officials have sometimes become quite outspoken towards the end of their term in office. Notably, former Minister of Planning and Investment Bui Quang Vinh, when commenting on socialist-oriented market institutions, has publicly said that "we keep studying that model, searching for it in vain.

7I. See e.g. HOANG Van Luan, "Interest Group and Some Issues on Interest Group in Vietnam” (20I4) 30 Journal of Social Sciences I.

72. See e.g. Nick DAVIES, "Vietnam 40 Years On: How a Communist Victory Gave Way to Capitalist Corruption", The Guardian (22 April 2015), online: The Guardian <http://www.theguardian.com/ news/20I 5/apr/22/vietnam-40-years-on-how-communist-victory-gave-way-to-capitalist-corruption>.

73. This warning was one of the messages that we raised in our joint research commissioned by UNDP Vietnam in 2009-20I0 on the need to institutional reform in Vietnam. The report was introduced to the public on September I3, 2010 and was fiercely debated in Vietnam's media, see "Chính phủ nên từ bỏ vai tổng quản với tài sản công [The Government shall refrain to act as manager of public property]", Tuan VietnamNet ( Iо October 20I0), online: Tuan VietnamNet <http://tuanvietnam.vietnamnet.vn/2010-09o8-chinh-phu-nen-tu-bo-vai-tong-quan-voi-tai-san-cong $>$.

74. GIA Bảo, "Nhận thức mới về kinh tế thị trường định hướng xã hội chủ nghĩa [New Understanding about Socialist Oriented Market Economy]", Communist Review (28 February 201 5), online: Communist Review <http://www.tapchicongsan.org.vn/Home/Thong-tin-ly-luan/2015/32 I63/Nhan-thuc-moi-vekinh-te-thi-truong-dinh-huong-xa-hoi.aspx $>$.

75. HA Chinh, "Hà Chính, Kinh tế thị trường và câu trả lời của Thủ tướng [Market Economy and the Prime Minister's Answer]", Báo Điện Tử Chính phủ [Online Newspaper of the Government] (9 March 20I 5), online: Báo Điện Tử Chính phủ <http://baodientu.chinhphu.vn/Tin-noi-bat/Kinh-te-thi-truong-va-cautra-loi-cua-Thu-tuong/22I732.vgp $>$.

76. Nguyen Dinh Cung, the main drafter of the liberal 1999 Law on Enterprise, is currently Director of the Central Institute of Economic Management (CIEM). NGUYÊN Thảo, "Đổi mới khái niệm "kinh tế thị trường định hướng xã hội chủ nghĩa'? [Renovating the Concept 'Socialist Oriented Market Economy'?]”, VnEconomy (2I April 20I5), online: VnEconomy <http://vneconomy.vn/thoi-su/doi-moi-khai-niemkinh-te-thi-truong-dinh-huong-xa-hoi-chu-nghia-20I 504I9IO2024689.htm >.

77. Tran Dinh Thien is the Director of VASS-Institute of Economic Research. CIEM and VASS are the leading think tanks for economic research in Vietnam. See Sự kiện NÓNG, "Chỗ cần nhà nước thì không thấy đâu” [The State Cannot be Found in Necessary Places]", VietnamNet (I April 20 I 5), online: VietnamNet $<$ http://vietnamnet.vn/vn/ban-tron-truc-tuyen/2296I $7 /$-cho-can-nha-nuoc-thi-khong-thay-dau-.html>. 
There is no such model to be found." ${ }^{78}$ Retired politicians have often called for liberalization when they no longer directly benefit from the current system. ${ }^{79}$ Examples include former Minister of Trade Truong Dinh Tuyen, who called for Vietnam to redefine its "socialist orientation" 80 and former Minister of Justice Nguyen Dinh Loc who led a group calling for a liberal constitution. ${ }^{81}$

The debates within Vietnam's political system leading to the $20{ }_{3} 3$ Constitution were far more vibrant as compared to the 200I Constitution. Ongoing changes to the political system allowed more stakeholders to participate..$^{82}$ While research institutions remained under government control, they were able to improve their capacity and test the little autonomy they enjoy in law and policy research. ${ }^{83}$ Quasi-non-governmental organizations were also allowed to articulate the critical concerns of their constituencies. ${ }^{84}$ Finally, due to rapid developments in public communication, the calls for reform were transmitted quickly from the political elite to the wider public. From these vibrant debates, the public have become aware that the internal contradictions and ambiguities of Vietnam's "socialist orientation" as provided in the constitution have hampered reform, and therefore need to be changed.

\section{Growing Expectation of the Public in Pushing for Liberal Reform}

Based on the principles and guidelines approved by the CPV, the Editing Board presented numerous versions of the Draft Constitution for internal discussion in $20 \mathrm{I} 2$.

78. TƯ Giang, "Cải cách thể chế từ câu hỏi chưa có lời giải [Institutional Reform from Unanswered Question]", The Saigon Times (5 March 20I4), online: The Saigon Times <http://www.thesaigontimes. vn/I I 430 I/Cai-cach-the-che-tu-cau-hoi-chua-co-loi-giai.html>.

79. For examples of the social elite resisting reform in Vietnam, see Martin GAINSBOROUGH, "Elites vs. Reform in Laos, Cambodia, and Vietnam" (2012) 23(2) Journal of Democracy 34.

80. TRƯƠNG Đình Tuyển, "Kinh tế thị trường hiện đại theo định hướng XHCN là gì? [What is Modern Socialist-Oriented Market Economy?]”, The Saigon Times (4 November 201 5 ), online: The Saigon Times <http://www.thesaigontimes.vn/I 28900/Kinh-te-thi-truong-hien-dai-theo-dinh-huong-XHCNla-gi.html>.

8I. Before Prime Minister (PM) Nguyen Tan Dung's (2006-20II) first term, there was a Research Commission at the Prime Minister's Office (PMRC), comprising some reform-minded advisors, such as Tran Xuan Gia, Le Dang Doanh, and Pham Chi Lan. The PMRC was suddenly dissolved in 2006 after the PM took office. After this event, some of these advisors created an independent think-tank called IDS (Institute for Development Studies). The IDS was led by Nguyen Quang A. Due to its critiques of the government, IDS was also quickly forced to close down in 2007. Although the think-tank was closed, its network of intellectuals remained and was able to organize further joint activities. They collected signatures to protest against the bauxite project in Vietnam's Tay Nguyen highlands; they also formed the group demanding for constitutional reform in January 20I3. Their request was initially signed by 72 wellknown persons, and was therefore dubbed "Group 72 ". Their request subsequently obtained tens of thousands of signatures from January to September 2013 .

82. Mark SIDEL, Law and Society in Vietnam: The Transition from Socialism in Comparative Perspective (Cambridge: Cambridge University Press, 2008).

83. Active participants in constitutional discourse during $20 \mathrm{II}_{\mathrm{I}}-20 \mathrm{I} 3$ include the NA-Legislative Institute, Ho Chi Minh City Law University, Vietnam National University Law School, and VASS-Institute for State and Law.

84. Notable participants include the Vietnam Federation of Bar Associations (VFB), the Vietnam Lawyer Association (VLA), the Vietnam Union of Science and Technology Associations (VUSTA), the Institute for Law and Development (VUSTA-PLD), and the Institute for Public Policies Studies. Video records of some very lively debates on constitutional reform organized by VUSTA-PLD are available online, such as “Tọa đàm 'Góp ý Sửa đổi Hiến pháp I992'”, Viện PLD, VUSTA (5) [Workshop on Collection of comments to I992 Constitution Amendment, organized by Institute for Law and Development]" (I8 March 20I3) (video), online: YouTube <https://www.youtube.com/watch?v=ivwQKP $40 \mathrm{OJI}>$. 
Despite being subject to further amendments, the draft was presented to the NA for the first reading in October 20I2, and its second reading took place in May 20I3. The draft was presented for public comments from January to the end of March 2013, and this period subsequently extended to the end of September 20I3. Finally, the NA voted on the Draft Constitution in November 2013.

According to the Editing Board, it received three million comments on the economic system from citizens. ${ }^{85}$ This number, although possibly exaggerated, ${ }^{86}$ reflects the growing awareness within Vietnamese society of constitutional issues. Beyond the established political system, information technology has enabled ordinary Vietnamese to be better informed on political and global issues. An estimated 40 million Vietnamese have access to the Internet and social media. ${ }^{87}$ Vietnamese youth have rapidly benefited from these phenomenal opportunities. ${ }^{88}$ These new mechanisms for public expression have proven to be challenging for the government. ${ }^{89}$ Rumours intended to damage political reputations have been circulated through the Internet and social media, and these have fanned the flames of internal discord within the CPV. ${ }^{90}$

Blogs, Facebook, and other forms of social media have enabled citizens to voice their concerns and proactively contribute to constitutional dialogue. Economic mismanagement, particularly the inefficiencies in public investment, failure of SOEs, and rampant corruption have elicited public anger. Calls for SOEs to be disciplined, and for the government to privatize land and strictly control scarce natural resources have reached millions of people through the Internet. Although the CPV has historically not welcomed the spontaneous and pluralistic civil society developed by netizens, it has been unable to prohibit it as well. ${ }^{9 \mathrm{I}}$ As such, so long as netizens do not directly attack the CPV's monopoly on power, they are generally tolerated..$^{92}$

As compared to China, social media and civil society seem to be less restricted in Vietnam. Most recently, citizens in Hanoi were able to come together to save the city's

85. Constitution Editing Board, Report of the Constitution Editing Board (I7 October 2013) (Chair: Phan Trung Ly) [unpublished], at 340-40.

86. The percentage of Vietnamese who have heard about the Constitution is extremely low. See UNDP, Justice Index: Assessment of Distributive Justice and Equality from a Citizen-based Survey in $20 \mathrm{I} 2$ (Hanoi: United Nations Development Programme, 20I3), online: <http:/www.vn.undp.org/content/ vietnam/en/home/library/democratic_governance/justice_index_report.html >.

87. Jason MORRIS-JUNG, "Vietnam's Online Petition Movement" (2015) Southeast Asian Affairs 402

88. Ian BRAND-WEINER, Francesca FRANCAVILLA \& Mattia OLIVARI, "Globalisation in Viet Nam: An Opportunity for Social Mobility?" (2OI 5 ) 2 Asia \& the Pacific Policy Studies 2 I.

89. David BROWN, "Vietnam's Communists Conjure with the Internet", Asia Sentinel (3 March 20I 5), online: Asia Sentinel <http://www.asiasentinel.com/politics/vietnam-communists-conjure-internet/? utm_content=buffer83a9a\&utm_medium $=$ social\&utm_source $=$ twitter.com $\& u t m \_c a m p a i g n=b u f f e r \%$ ${ }_{3}$ E\#frameId=appnext_widget\&height $=64>$.

90. "Online rumor mills could create political chaos", Nikkei Asian Review (I4 January 20I 5), online: Nikkei Asian Review <http://asia.nikkei.com/Politics-Economy/International-Relations/Online-rumormills-could-create-political-chaos>.

9I. Thiem H BUI, “The development of civil society and dynamics of governance in Vietnam's one party rule" (2013) 25(I) Global Change, Peace \& Security 77.

92. This may explain why Group 72, or blogs devoted to constitutional dialogue, such as NGO Bao Chau, DAM Thanh Son \& NGUYEN Anh Tuan, "Cùng viết Hiến pháp [Together Writing the Constitution]" online: <https://cungviethienphap.wordpress.com/ > are tolerated. 
cherished trees. ${ }^{93}$ Netizens were free to organize activities opposing the city's policy in order to rescue 6,700 trees in Hanoi. ${ }^{94}$ In South Vietnam, 90,000 workers organized a collective strike which lasted 4 days, ${ }^{95}$ and demanded changes to the recently enacted Social Insurance Law, which is expected to come into force in early $2016 .{ }^{96}$ Vietnamese people expect more accountability from the government. They have looked for ways to publicly voice their concerns and mobilized themselves to demand government attention on important issues. ${ }^{97}$ Public discontent may also grow during an economic slowdown and vulnerable groups are likely to express their anger at the state. ${ }^{98}$

In contrast to Vietnam's official “socialist orientation", the Vietnamese on the ground have overwhelmingly supported a pro-market approach, as demonstrated by various domestic surveys ${ }^{99}$ and international studies. ${ }^{\text {Io0 }}$ Beyond constitutional changes, they expect the government to express a clear commitment towards a free market economy. In particular, the Vietnamese hope that their rights in land are secure; that their private property will be protected effectively; and that their freedom to conduct any kind of business is protected subject to the law.

In light of the purported three million comments received by the Editing Board on the economic system, it is unsurprising that the Vietnamese expect that Vietnam's "socialist orientation" will not be abused to benefit inefficient SOEs, and by extension, monopolistic oligarchies controlling the nation's economic resources. Rather, Vietnamese citizens have called for secure land use rights and even land privatization. There have been public calls for the dominance of SOEs to come to an end, for the equal and just treatment of the private sector, and for fair access to the market. In essence, the people have become aware that the constitution should protect their civil rights in property and that the same rights should be extended to private businesses. The Vietnamese are no longer content to be mere recipients of the state's commands - they are demanding real change. ${ }^{\text {Ior }}$

93. Michael PEEL, "Hanoi residents mobilise to save city's cherished trees", Financial Times (27 March 20I 5), online: Vietnam Studies <http://www.viet-studies.info/kinhte/HanoiTrees_FT.pdf>.

94. MINH Anh, "Cộng đồng mạng tìm cách 'cứu' 6700 cây xanh Hà Nội [The Internet Community Tries to 'Rescue' 6700 Trees in Hanoi]”, Tuổi Trẻ [Youth Newspaper] (i9 March 2015), online: Tuổi Trẻ $<$ http://tuoitre.vn/tin/chinh-tri-xa-hoi/moi-truong/201 503 I9/cong-dong-mang-tim-cach-cuu-6700-cayxanh-ha-noi/722606.html>.

95. LE Tuyet, "Đình công bước sang ngày thứ 4, gây tắc nghẽn Quốc lộ IA [Strike goes on the third day, blocking the national road IA]" Lao Động [Labour] (30 March 20I5), online: Lao Động <http:// laodong.com.vn/cong-doan/dinh-cong-buoc-sang-ngay-thu-4-gay-tac-nghen-quoc-lo-ra-3 I037 r.bld>.

96. Tu Phuong NGUYEN, "Vietnam strikes out at labour disputes", East Asian Forum (Io April 2015), online: East Asian Forum <http://www.eastasiaforum.org/201 5/04/Io/vietnam-strikes-out-at-labourdisputes/>.

97. BUI Hai Thiem, "In Search of a Post-Socialist Mode of Governmentality: The Double Movement of Accommodating and Resisting Neo-Liberalism in Vietnam" (2OI 5 ) 43 Asian Journal of Social Science 80.

98. NGUYEN Dieu Tu Uyen, "Rage Against the State: Discontent Grows in Vietnam”, Bloomberg (I 5 May 20I5), online: Bloomberg <http://www.bloomberg.com/news/articles/20I5-O5-I 4/in-communistvietnam-rising-discontent-with-state-driven-system $>$.

99. VCCI (2OI 2), Changing Attitudes to the Market and the State (CAMS), updated 23 July 20I4, see CAMS 20I4: <http://vccinews.com/news_detail.asp?news_id=32424>.89\% of Vietnamese surveyed said that they are pro-market.

Iо०. Ezra KLEIN, "Free markets are more popular in Vietnam than in America”, Vox (3 May 20I 5), online: Vox <http://www.vox.com/20I 5/5/3/8539365/vietnam-capitalism-pew?>.

гог. Social media played an extraordinary role in promoting liberal ideas during 20II-20I3, especially through the blog anbbasam, which used different domain names. The blog provided links to many 
In an attempt to reflect this spectrum of views, the Draft Constitution presented to the NA in October 2OI 2 adopted a rather unique structure. For constitutional provisions on which there was no consensus, the Editing Board provided different permutations for each provision. For instance, the present Article 5I of the 20I3 Constitution was intensely debated during the drafting process. The first section of this Article attempts to define the nature of Vietnam's "socialist-oriented market economy”. From October $20{ }_{2}$ to September $20 I_{3}$, this section was drafted with two options: the first preserved the dominance of the public sector, while the second focused on fair competition and market discipline, without drawing a distinction between the private and public sectors. ${ }^{\text {IO2 }}$ The final version of Article 5 I adopted the first option and deleted the second. Further, the present Article 54 of the $20 I_{3}$ Constitution, which dealt with the public ownership of land, was also a political compromise. An early draft of this Article included an additional option for land use rights to be considered as a property right, ${ }^{\mathrm{IO}}$ but this option was also deleted in the final version of the $20 I_{3}$ Constitution. Although not all public demands were fully reflected during the drafting process, some made their imprint in the very first versions of the Draft Constitution. In this sense, the dialogue between the CPV and Vietnam's changing society was very beneficial for the constitutional movement in Vietnam.

\section{CONCLUSION}

The provisions on Vietnam's economic order, as stipulated by the 2013 Constitution, are in essence an ideological compromise reached by various stakeholders after almost three years of vibrant debate. Vietnam has inched forward towards a free market economy in the 2013 Constitution, although it was by no means a radical step towards a liberal constitution. The 2013 Constitution of Vietnam inherited much from its socialist past, and it continues to suffer from considerable uncertainty on property matters, particularly in land and natural resources, and from the dominance of the inefficient public sector.

From 20I I to 20I3, Vietnam experienced a vibrant constitutional discourse on the way forward for its economy. From internal CPV discussions to public debates, this constitutional discourse contributed to social consensus and compromise. With regard to Vietnam's economic order, this compromise may at least be understood in the five following aspects.

influential Vietnamese bloggers, creating powerful online networks that could share knowledge and establish joint actions demanding for civil rights. The owner of anhbasam was then identified and arrested by Vietnam's public security in May 20I4. In March 2016 he was sentenced to 5 years in jail. See Associated Press, "Protests as Vietnamese blogger goes on trial for 'anti-government' posts", The Guardian (23 March 20I6), online: The Guardian <http://www.theguardian.com/world/20I6/mar/23/ protests-as-vietnamese-blogger-goes-on-trial-for-anti-government-posts $>$.

I02. Compare the draft of Constitution as modified in October 20I2, September 20I3 and October 20I3, all provided by the Editing Board.

I03. Personal interview with Mr Tran Du Lich, NA member and a member of the Editing Board, Hanoi, Vietnam (I 5 June 20I 5 ). 
First, in contrast to Vietnam's political order in Chapter I of the $20 \mathrm{I}_{3}$ Constitution, which is assumed to be fundamental and remains unchanged, Vietnam's economic order is subject to steady change. The drafters of the new constitution considered Vietnam's economic order as essential to the strategic orientation of Vietnam's growth model. The economic order should therefore be understood as a summary of the guiding principles for Vietnam's economic policies. For this purpose, the guiding principles for economic policies are now subordinated under the new Chapter III, comprising economic, cultural, educational, science, technological, and environmental policies.

Second, the drafters of the $20 \mathrm{I}_{3}$ Constitution attempted to keep the constitutional provisions on Vietnam's economic order abstract and general in order to enable them to function as guiding principles. In this sense, the $20 I_{3}$ Constitution envisages that the CPV will merely be responsible for management of the economy. The $20{ }_{3} 3$ Constitution continues to be of paramount importance within Vietnam's legal hierarchy according to socialist principles. It basically demonstrates the will of the CPV, although it has incorporated various views from the public. Compared to liberal constitutions, the $20 \mathrm{I} 3$ Constitution was not drafted with the ultimate aim of constraining political power in order to protect individual liberties. It is also not expected to be binding law which individuals may rely on. However, the 2013 Constitution will form the foundation for future legislation. Economic laws and regulations have to conform to these guiding principles as provided by the $20 \mathrm{I}_{3}$ Constitution.

Third, as a political compromise, the $20 \mathrm{I}_{3}$ Constitution continues to preserve the ambiguity surrounding Vietnam's “socialist orientation", the "dominance of state's economic sector", and "the entire people's ownership of productive means". ${ }^{\text {I04 The }}$ power to interpret this ambiguity is neither vested with the Standing Committee of the NA, ${ }^{\text {105 }}$ nor with the Supreme People's Court. ${ }^{\text {I06 }}$ It can only be clarified through policies adopted by the CPV and by the enormous body of legal documents issued by the state apparatus. This ambiguity may allow state agencies to issue laws and administrative regulations, which unreasonably restrict individual liberties. ${ }^{\text {I07 }}$

Fourth, the 2013 Constitution also contains a number of contradictions. The Constitution protects the dominance of the state's economic sector, but simultaneously commits fully to market rule. ${ }^{\text {I08 }}$ The Constitution recognizes private property and promises to protect them, but simultaneously declares that all land is public and that the government can appropriate land if it considers it necessary. The government's

\footnotetext{
I04. 2013 Constitution, supra note I, arts $5 \mathrm{I}$ and 53.

I05. Ibid, art 74.2 provides that the NA Standing Committee shall have the right to interpret the Constitution. However, as matter of fact, this Committee has never done so during Vietnam's 70 years of constitutional history.

I06. The Constitution left the issue of constitutional review relatively open, and provided that "constitutional review mechanism shall be provided by law". Ibid, art I I9.2

107. Vietnam Minister of Planning and Investment Bui Quang Vinh repeated his warning that law and regulation may unreasonably restrict constitutional liberties, such as the freedom to conduct business. He therefore said that “don't let the Constitution be open, but the law be closed”, see BUI Quang Vinh, “Đừng để Hiến pháp mở, Luật đóng [Don’t let Constitution opens, but Law closes]”, Tuổi trẻ [Youth Newspaper] (I7 June 20I5), online: Tuổi trẻ <http://tuoitre.vn/tin/chinh-tri-xa-hoi/thoi-su-suy-nghi/ 201 506 I $7 /$ dung-de-hien-phap-mo-luat-dong/762630.html>.

Iо8. Compare 2013 Constitution, supra note I, art 5 I.I with art 52.
} 
right to appropriate land does not seem to be sufficiently restricted, given that it may do so where national defence, public security, national economic and social development, and public purposes are concerned. ${ }^{\text {I09 }}$ Obviously, the generous right granted to the government for land appropriation clearly contradicts an individual's right to private property.

Fifth, the debate on Vietnam's economic order is still ongoing. The ambiguity and contradictions in the $20 \mathrm{I}_{3}$ Constitution on the roles of state versus the market in economic management, and on the distinction between public and private property, continue to hamper and impede Vietnam's present economic growth. Despite the promulgation of the $20 I_{3}$ Constitution, most of these questions remain unanswered. The internal political struggle within the CPV for an alternative economic growth model will be the decisive factor that determines how Vietnam's new leadership, as elected after the $2^{\text {th }}$ Party Congress in 2016, will confront these challenges.

I09. Compare 2013 Constitution, supra note I, art 32 with art 54.3. 